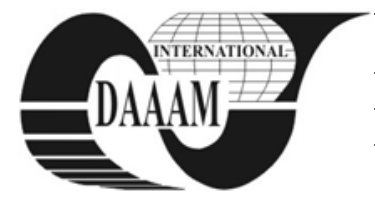

Annals of DAAAM for 2011 \& Proceedings of the 22nd International DAAAM Symposium, Volume 22, No. 1, ISSN 1726-9679 ISBN 978-3-901509-83-4, Editor B. Katalinic, Published by DAAAM International, Vienna, Austria, EU, 2011 Make Harmony between Technology and Nature, and Your Mind will Fly Free as a Bird Annals \& Proceedings of DAAAM International 2011

\title{
CONTROL OF TEMPERATURE IN LABORATORY MODEL OF HOT-AIR TUNNEL
}

\author{
MATUSU, R[adek] \& PROKOP, R[oman]
}

\begin{abstract}
This contribution deals with control of bulb temperature in laboratory model of hot-air tunnel under assumption of parametric uncertainty in the controlled plant. The controller design is based on algebraic approach and closed-loop robust stability is analyzed via the value set concept and the zero exclusion condition
\end{abstract}

Key words: temperature control, algebraic synthesis, parametric uncertainty, hot-air tunnel

\section{INTRODUCTION}

The key problem of real control applications is a ubiquitous uncertainty - especially if a cheap controller with simple structure is required, which is common in practice. So, investigation on design methods for such controllers is still very topical.

This paper is focused on control of bulb temperature in laboratory model of hot-air tunnel (Smutný et al., 2002) while the controlled plant is modelled as a system with parametric uncertainty. The control design is based on general solutions of Diophantine equations in the ring of proper and stable rational functions $\left(\mathrm{R}_{\mathrm{PS}}\right)$, Youla-Kučera parameterization and divisibility conditions (Vidyasagar, 1985; Kučera, 1993). The subsequent robust stability analysis uses the combination of the value set concept and the zero exclusion condition (Barmish, 1994).

\section{LABORATORY MODEL OF HOT-AIR TUNNEL}

The control experiments have been done on laboratory model of hot-air tunnel constructed in VŠB - TU of Ostrava (Smutný et al., 2002). The model is composed of the bulb, primary and secondary ventilator, and number of sensors covered by tunnel as shown in fig. 1. The bulb is powered by controllable source of voltage and serves as the source of light and heat energy while the purpose of ventilators is to ensure the flow of air inside the tunnel. All components are connected to the electronic circuits which adjust signals into the voltage levels suitable for CTRL 51 unit (Klán et al., 2003). Then, the control unit is connected with the PC via serial link RS232 (Dušek \& Honc, 2002).

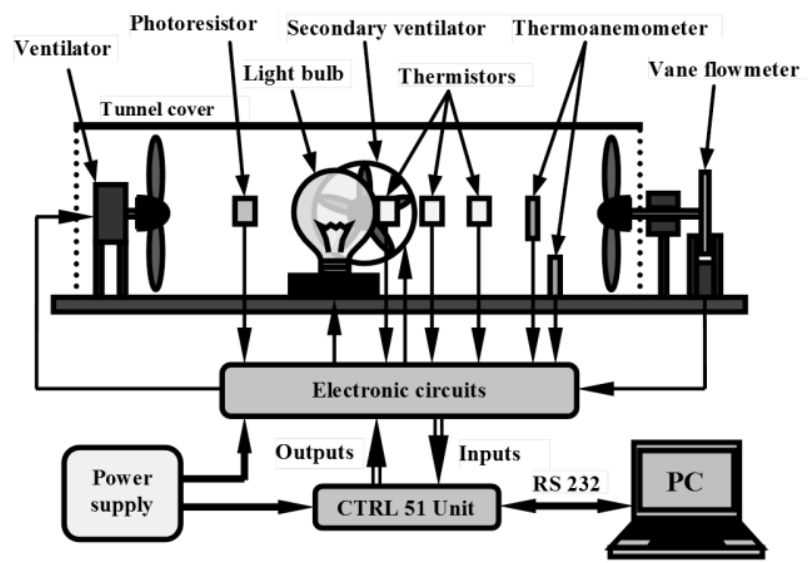

Fig. 1. Diagram of hot-air tunnel and control system
The selected controlled system consists of bulb voltage $u 1$ (input, actuating signal), which influences temperature of the bulb y3 (output, controlled variable). The identification experiments performed in various operational points have led to the description of the system via second order mathematical model with parametric uncertainty where the time constants are given in seconds (Matušů \& Prokop, 2007; Matušů \& Prokop, 2008; Matušů et al., 2008; Matušů \& Prokop, 2011):

$$
\begin{aligned}
& G\left(s, K, \tau, T_{1}, T_{2}\right)=\frac{K(\tau s+1)}{\left(T_{1} s+1\right)\left(T_{2} s+1\right)}= \\
& =\frac{[0.2 ; 0.7]([25 ; 130] s+1)}{([3 ; 14] s+1)([70 ; 210] s+1)}
\end{aligned}
$$

This model is going to be used in section 4 in order to design a PI controller and verify the closed-loop robust stability.

\section{ALGEBRAIC DESIGN OF CONTROLLERS}

The utilized continuous-time controller design technique is based on fractional approach developed in (Vidyasagar, 1985; Kučera, 1993) and discussed e.g. in (Prokop \& Corriou, 1997). The method supposes description of systems and signals in $\mathrm{R}_{\mathrm{PS}}$. Usually, standard one-degree-of-freedom (1DOF) or twodegree-of-freedom (2DOF) control structures are used.

The control synthesis itself consists of solution of Diophantine equation(s) in $\mathrm{R}_{\mathrm{PS}}$, Youla-Kučera parameterization which leads to expression of all stabilizing controllers, and application of divisibility condition(s) which assists with the selection of the controller from the stabilizing pool according to the user requirements such as asymptotic tracking, disturbance rejection, etc. (Prokop \& Corriou, 1997; Prokop et al., 2002).

Finally, the controller can be tuned and especially its dynamical properties can be influenced via the single parameter $m>0$ (Matušů \& Prokop, 2008; Matušů \& Prokop, 2011)

Possibly, robust stability of the closed control loop can be additionally analyzed, among other methods, by means of graphical approach based on combination of the value set concept and the zero exclusion condition (Barmish, 1994).

\section{ROBUST CONTROL EXPERIMENT}

The controlled system is given by (1). The nominal system for control design is obtained using the fixation of interval parameters from (1) and subsequent simple approximation:

$$
\frac{0.5(100 s+1)}{(9 s+1)(150 s+1)} \approx \frac{0.5}{159 s+1}=\frac{0.003145}{s+0.006289}=\frac{b_{0}}{s+a_{0}}=G_{N}(s)
$$

Now, the PI controller can be designed using the algebraic approach which has been outlined in section 3, more specifically with assistance of simple relations (Matušů \& Prokop, 2008; Matušů \& Prokop, 2011): 


$$
C(s)=\frac{\tilde{q}_{1} s+\tilde{q}_{0}}{s} ; \quad \tilde{q}_{1}=\frac{2 m-a_{0}}{b_{0}} ; \quad \tilde{q}_{0}=\frac{m^{2}}{b_{0}}
$$

where the tuning parameter is chosen as $m=2.8 a_{0} \square 0.01761$ (Matušů \& Prokop, 2008; Matušů \& Prokop, 2011). So the final 1DOF PI controller is:

$$
C(s)=\frac{\tilde{q}_{1} s+\tilde{q}_{0}}{s}=\frac{9.199 s+0.0986}{s}
$$

The closed-loop characteristic polynomial of the family of plants (1) and the controller (4) can be expressed as:

$$
\begin{aligned}
& p_{C L}\left(s, K, \tau, T_{1}, T_{2}\right)=\left(T_{1} s+1\right)\left(T_{2} s+1\right) s+K(\tau s+1)\left(\tilde{q}_{1} s+\tilde{q}_{0}\right)= \\
& =T_{1} T_{2} s^{3}+\left(T_{1}+T_{2}\right) s^{2}+K \tau\left(\tilde{q}_{1} s^{2}+\tilde{q}_{0} s\right)+K\left(\tilde{q}_{1} s+\tilde{q}_{0}\right)+s
\end{aligned}
$$

where controller parameters are fixed and taken from (4), and where controlled plant parameters $K, \tau, T_{1}, T_{2}$ can vary within given intervals from (1).

The robust stability of this family of polynomials can be investigated e.g. using combination of the value set concept and the zero exclusion condition (Barmish, 1994). Convenient tool for plotting the value sets is represented by the Polynomial Toolbox (PolyX, 2011; Šebek et al., 2000). It was applied also for obtaining fig. 2 which shows the value sets of polynomial family (5). The origin of the complex plane is excluded from the value sets and the family has a stable member which means that the closed-loop polynomial (5) and consequently the whole closed control loop is robustly stable. This is confirmed also by fig. 3 where the bulb temperature control data are visualized.

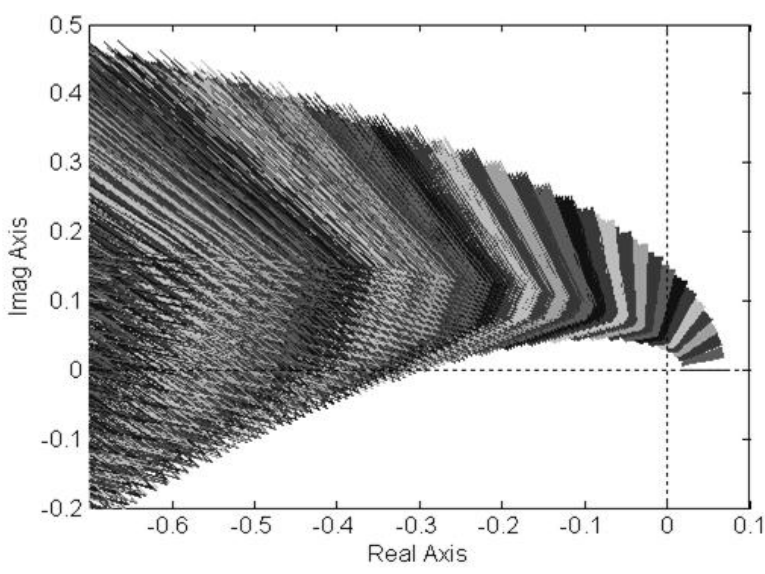

Fig. 2. Value sets of (5) from the Polynomial Toolbox

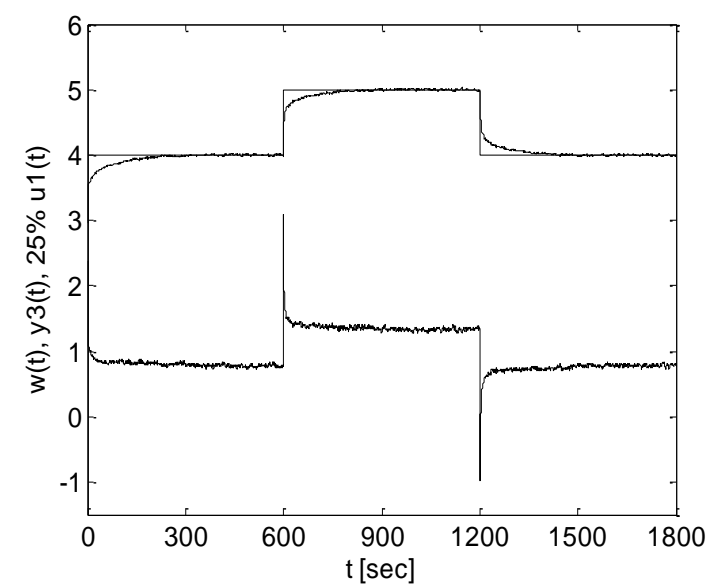

Fig. 3. Control of bulb temperature in hot-air tunnel

\section{CONCLUSION}

The main aim of the contribution was to present the application of algebraic approach to control design for bulb temperature in laboratory model of hot-air tunnel. The synthesis was based on solution of Diophantine equations in $R_{\mathrm{PS}}$, YoulaKučera parameterization and conditions of divisibility. As the controlled plant had been modelled as the system with parametric uncertainty, robust stability of the closed control loop was graphically verified using the value set concept and the zero exclusion condition. The performed control experiment has indicated practical applicability of considered method.

\section{ACKNOWLEDGEMENTS}

The work was supported by the Ministry of Education, Youth and Sports of the Czech Republic under the Research Plan No. MSM 7088352102 and by the European Regional Development Fund under the project CEBIA-Tech No. CZ.1.05/2.1.00/03.0089. This assistance is very gratefully acknowledged.

\section{REFERENCES}

Barmish, B. R. (1994). New Tools for Robustness of Linear Systems, Macmillan, ISBN 0-02-306055-7, NY, USA

Dušek, F. \& Honc, D. (2002). Využití sériové linky pod MATLABem verze 6, (Utilization of serial link under MATLAB 6), In: Proceedings of conference MATLAB 2002, Prague, Czech Republic, (In Czech)

Klán, P.; Honc, D. \& Jindřich, J. (2003). Nová měřicí jednotka CTRL V3, (New measuring unit CTRL V3), In: Proceedings of conference MATLAB 2003, Prague, Czech Republic, (In Czech)

Kučera, V. (1993). Diophantine equations in control - A survey. Automatica, Vol. 29, No. 6, pp. 1361-1375

Matušů, R. \& Prokop, R. (2007). Design and practical application of simple robust controllers: a parametric approach, In: Proceedings of IEEE Multi-conference on Systems and Control, Singapore

Matušů, R. \& Prokop, R. (2008). Single-Parameter Tuning of PI Controllers: From Theory to Practice, In: Proceedings of the 17th IFAC World Congress, Seoul, Korea

Matušů, R. \& Prokop, R. (2011). Single-parameter tuning of PI controllers: Theory and application. Journal of The Franklin Institute, Vol. 348, No. 8, pp. 2059-2071

Matušů, R.; Prokop, R. \& Dlapa, M. (2008). Robust Control of Temperature in Hot-Air Tunnel, In: Proceedings of the 16th Mediterranean Conference on Control and Automation, Ajaccio, France

PolyX: The Polynomial Toolbox. (2011). [Online]. [Accessed July 15, 2011]. Available from URL: http://www.polyx.com/

Prokop, R. \& Corriou, J. P. (1997). Design and analysis of simple robust controllers. International Journal of Control, Vol. 66, No. 6, pp. 905-921, ISSN 0020-7179

Prokop, R.; Husták, P. \& Prokopová, Z. (2002). Simple robust controllers: Design, tuning and analysis, In: Proceedings of the 15th IFAC World Congress, Barcelona, Spain

Šebek, M.; Hromčík, M. \& Ježek, J. (2000). Polynomial toolbox 2.5 and systems with parametric uncertainties, In: Proceedings of the 3rd IFAC Symposium on Robust Control Design, Prague, Czech Republic

Smutný, L.; Škuta, J. \& Farník, J. (2002). Model teplovzdušného obvodu, (Model of hot-air circuit), Technical report to HS 311107 "Technická pomoc při návrhu a zhotovení modelu teplovzdušného obvodu", VŠBTU Ostrava, Czech Republic, (In Czech)

Vidyasagar, M. (1985). Control system synthesis: a factorization approach, MIT Press, Cambridge, MA, USA 